\title{
Nexus between Cost Leadership Strategy and Performance: Fact or Fallacy in Milk Processing Firms in Kenya
}

\author{
Paul G. Kimiti ${ }^{1}$, Stephen M.A. Muathe ${ }^{1}$, Elishiba M. Murigi ${ }^{1}$ \\ ${ }^{1}$ School of Business, Kenyatta University, Kenya \\ Correspondence: Paul G. Kimiti, School of Business, Kenyatta University, Kenya.
}

Received: August 7, 2020

Accepted: August 26, $2020 \quad$ Online Published: September 4, 2020

doi:10.5539/ibr.v13n10p1

URL: https://doi.org/10.5539/ibr.v13n10p1

\begin{abstract}
Milk processing firms as a constituent of the food processing sector play a crucial function both economically and nutritionally. However, performance in the industry continues to be impended by high costs leading to low profitability margins, decline in output and collapse of some firms while others show stunted growth. It is hypothesized that this situation can be remedied by pursuing cost leadership strategy through economies of scale, economies of scope and operational efficiency. Extant literature however is scanty on how this strategy is employed by milk processing firms in Kenya with studies done failing to focus on how the firms manage costs as a driver for better performance. This has made it difficult to determine whether the hypothesized effect is a fact or fallacy. This study thus was an investigation of the effect of cost leadership strategy on performance of milk processing firms in Kenya. It was anchored on the balanced scorecard model complemented by the resource based view and capability based view theories. The study empirically examined the relationship using data from milk processing firms in Kenya obtained from a sample of 168 key respondents. The findings showed that cost leadership strategy had a positive and significant effect on performance of milk processing firms in Kenya. The study recommends that milk processors improve their performance by cutting costs through measures to increase their scale of operations, expand into related business areas and improve operational processes. The government and other the regulatory bodies should implement corresponding supportive policies and reforms.
\end{abstract}

Keywords: firm performance, cost leadership strategy, milk processing firms in Kenya

\section{Introduction}

The Kenya food processing sector is a major driver of economic growth in the country (Kyengo Muathe \& Kinyua, 2019). It is among the sectors currently considered essential services within the framework of measures against COVID-19 pandemic (Government of Kenya, 2020). The milk processing industry which is part of this sector similarly plays important nutritional and economic roles in the lives of many people (Wambugu, Kirimi \& Opiyo, 2011). This has as a consequence necessitated numerous reforms and policy support to the industry including tax rebates on new investments and zero rating of milk processing inputs (Ministry of Agriculture, Livestock and Fisheries, 2013). In terms of employment, the milk industry generates around 500,000 jobs in direct waged employment and additional 750,000 jobs in related supportive services (Mwangi \& Gakobo, 2018).

However, despite opportunities and potential for growth, the milk processing firms continue to record poor performance characterized by low profit margins (Bebe, Rademaker, Lee, Kilelu \& Tonui, 2017). Conversely, milk uptake by the processors declined from 58\% in 2000 to about $30 \%$ in 2017 further suggesting declining performance (Chege \& Oloko, 2017). This was despite rising demand for dairy products (Kenya Agribusiness \& Agroindustry Alliance, 2014). Poor performance has also led to collapse of some of the processors while others show stunted growth (Mwangi \& Gakobo, 2018). Kyengo et al. (2019) further observed that general contribution of food processing firms to the GDP has been declining over time. The low performance has been made worse by the COVID-19 pandemic due to the severe disruption to the economy.

In addressing high costs which is a major challenge for firms, cost leadership strategy has been found to be a significant contributor to superior performance in various sectors (Hilman \& Kaliappen, 2014; Gorondutse \& Gawuna, 2017). Hansen, Nybakk and Panwar (2015) further observed that the strategy is the most widely adopted from among the three Porter's generic competitive strategies. Extant literature however is scanty on how cost leadership strategy is employed by milk processing firms in Kenya with studies done failing to focus on how the firms manage costs as a driver for better performance. This study sought to address this gap by 
conducting a descriptive and explanatory study on the milk industry in Kenya. Primary data was obtained from all firms in the industry and subsequently analyzed using descriptive and inferential statistics.

The study findings indicated that all the three drivers of cost leadership strategy namely economies of scale, economies of scope and operational efficiency were adopted by firms to varying extents. Further, all the drivers had positive and significant effect on performance of milk processing firms in Kenya. The findings serve as a basis to inform cost cutting measures by firms by increasing their scale of operations, expanding into related businesses and improving their operational processes. The upcoming sections of the study cover the background, literature review, methodology, findings and discussions and finally a conclusion and recommendations.

\section{Background}

The milk processing industry in Kenya comprises of 29 firms (Kenya Dairy Board - KDB, 2019). The firms are spread throughout the country producing a wide range of milk products. The industry is extremely competitive with the main competitive challenge being able to produce low cost products for a market population most of whom live below the poverty line. Rivalry in the local market has also been worsened by import of processed milk products from Europe. The key question for the processors remains how to lower costs as a gateway to attaining superior performance relative to competitors.

Superior firm performance is a central theme in strategic management (Njoroge, Ongeti, Kinuu \& Kasomi, 2016; Kimiti \& Kilika, 2018; Echwa \& Murigi, 2019) with good firm performance defining the very existence of a firm. Kiiru (2015) asserted that well performing firms play important roles for both individuals and national economy. Firm performance describes how well a firm achieves its set objectives (Kirima \& Murigi, 2019). It also defines the firm's position in an industry hence the higher the performance the better a firm is relative to competitors.

Firm performance is associated with both financial and non-financial measures (Kathama, 2012; Karanja, Muathe \& Thuo, 2014). However, either of these measures has inherent limitations (Chong, 2008; Hubbard, 2009; Fatoki, 2011; Echwa \& Murigi, 2019). Financial measures despite being objective are too narrow in focus and internally oriented (Ongeti, 2014; Kimiti \& Kilika, 2018). Conversely, non-financial measures while providing a better picture on employment of resources, competitive position and future prospects of a firm suffer from being too subjective (Chong, 2008). This therefore calls for an all inclusive assessment of firm performance by considering all its dimensions through broad measurement (Wanjiru, Muathe \& Kinyua-Njuguna, 2019).

Owing to the centrality of superior performance, it becomes necessary that firms apply specific approaches to address prevailing performance challenges more so high costs. These approaches are the strategies adopted to effectively guide firms towards their performance objectives (Elif \& Şengül, 2015). Cost leadership strategy is among the most widely studied strategic orientations whose effect on firm performance has been empirically ascertained (Theodosiou, Kehagias \& Katsikea, 2012; Birjandi, Jahromi, Darasi \& Birjandi, 2014; Hilman \& Kaliappen, 2014; Nyauncho \& Nyamweya, 2015; Gorondutse \& Gawuna, 2017). It is the most pursued competitive option in pure strategy firms and in addition, success of a hybrid strategy depends on the inclusion of low cost as the dominant component (Spanos, Zaralis \& Lioukas, 2004; Hansen et al., 2015). Among the different drivers of cost leadership strategy, economies of scale, economies of scope and operational efficiency are the most commonly adopted (Atikiya, Mukulu, Kihoro \& Waiganjo, 2015).

Under economies of scale, costs are reduced when efficiency increases through improved training, better positioning, additional time on the organization and better technology (Mosheim \& Lovell, 2009). Conversely, Barney and Hesterly (2009) viewed economies of scale as falling average cost per unit produced as quantity increases. Scale economies in production may either be internal or external economies (Gill \& Goh, 2009). Internal economies of scale arise from pure size of a firm without reference to the industry or market while external scale economies relate to benefits from outside a firm but within an industry (Anwar \& Ali, 2015).

Economy of scope on the other hand focuses on combining production activities rather than quantity. The combination of production processes allows organizations to efficiently multi-task related skills or resources, optimally exploit available resources, achieve synergies in business operations and also facilitate redeployment of resources (Zahavi \& Lavie, 2013). Sakhartov (2017) distinguished two types of economies of scope; intra-temporal and inter-temporal. Intra-temporal economies arise when resources are shared among business areas while inter-temporal economies arise when a resource is withdrawn from one business and redeployed in another.

Finally, operational efficiency is a product of cost control among other factors. Gill, Singh, Mathur and Mand (2014) posited that to survive and prosper, firms should operate efficiently by consuming same output to produce 
more, producing same output with less input, reducing operating risk and reducing operating costs. Operational efficiency is influenced by effectiveness in execution of organizational processes (Espirah \& Murigi, 2019). It enhances the productivity of a firm while minimizing the cost of routine operations (Dhillon \& Vachhrajani, 2012).

\section{Review of Literature}

\subsection{Theoretical Review}

\subsubsection{Balance Scorecard}

Balance Scorecard (BSC) was introduced by Kaplan and Norton (1992) and it is the most widely adopted broad performance measure by firms. It was introduced at a time when firm dynamics were rapidly changing rendering the traditional financial measures insufficient (Niven, 2011). It thus expanded financial performance metrics by augmenting them with three additional perspectives; customer, internal process, and learning and growth (Hoque, 2014). It has over time developed into an instrument for the management to describe, communicate and implement strategy (Kaplan, 2009) as well as a theoretical foundation to guide the research questions and methodology in various studies (Krylov, 2019; Sainaghi, Phillips \& d'Angella, 2019).

Measurement of performance is important to facilitate performance improvement. BSC provides for broad measures thus allowing guidance and assessment of firm strategy through a variety of financial and non-financial tools. It balances the traditional precision and reliability of financial measures with the drivers of future financial performance (Niven, 2011). It depicts firms as more than mere sources of profits for the shareholders and thus validates accountability to external stakeholders (Sundin, Granlund \& Brown, 2010).

The financial perspective focuses on shareholders' interests (Martello, Watson \& Fischer, 2016) while the customer perspective is concerned with the firm's customers (Niven, 2011). Conversely, the internal business perspective relates to business processes which lead to customer and shareholder satisfaction (Booyse, 2018). Learning and growth perspective describes approaches that facilitate innovation and growth. Thus as firms implement cost leadership strategy, the outcomes should relate to the broad performance objectives beyond the financial returns.

\subsubsection{Resource Based View}

Resource Based View (RBV) on the other hand arose from the seminal works of Penrose (1959) who suggested that firm performance was pegged on the resources it possessed. RBV is consequently one of the most influential paradigms in strategic management in understanding the competitive strategies pursued by firms. The greatest value of the theory lies in realizing that superior performance originates from doing things differently (Armstrong \& Baron, 2004). Thus, firms that employ cost leadership strategy in unique ways will perform better in the industry. Firm resources provide means with which to formulate and implement advantageous strategies leading to superior performance. RBV advances two principal arguments, resource heterogeneity and resource immobility. Resource heterogeneity distinguishes firms from competitors (Barney, 1991) hence ability to pursue unique strategies to outperform competitors. Resource immobility holds that resources are largely stationary across organizations thus sustaining heterogeneity.

A possible extension of the RBV application in regard to cost leadership strategy is difference in the human resource and knowledge possession by firms and in the potential for absorbing it in the future. Implementation of competitive strategies requires that firms be aware of the dynamics of competition (Ormanidhi \& Stringa, 2008). The higher the stock of knowledge about the competitive environment a firm has, the better it is in identifying and implementing the best strategic approaches. Further, innovative approaches by firms to lower costs are based on the absorptive capacity which is the ability to gain knowledge and use it to better performance. Ormanidhi and Stringa (2008) argue that the level of absorptive capacity depends on the current knowledge resource possession. Thus, it is the amount and type of resources possessed by a firm that define it and consequently the uniqueness of the strategy it employs. The human resource is crucial in such strategic choices.

\subsubsection{Capability Based View}

The Capability Based View (CBV) was introduced by Stalk, Evans and Shulman (1992) and later received major contributions from Teece and Pisano (1994). It is an offshoot of its predecessor, the RBV and thus sought to address a major limitation of the RBV in that it largely focused on the existing state of the firm's internal factors. As a consequence, RBV failed to explain how some initially vibrant firms deteriorated as competition increases. Such firms simply failed to adapt (Harreld, O'Reilly \& Tushman, 2007) through adoption of relevant strategies. Monsur and Yoshi (2012) noted that CBV also logically extends Porter's generic competitive strategies including cost leadership strategy. 
CBV recognizes that firms operate in highly competitive environment that is continuously changing and therefore competitive advantage is largely transient. Consequently, to sustain competitive advantage, firms require to regularly adjust to competitive pressures in the environment by constantly refining their strategic orientation. CBV in this regards advocates for creation of dynamic capabilities (Teece, Pisano \& Shuen, 1997). These allow firms to attain novel and innovative types of competitive advantage given the existing market positions. Barney (2001) observed that to create any advantage, a firm needs to develop such capabilities to transform strategy from theory into practice. Therefore, while cost leadership strategy may confer firms with competitive advantages, it is through dynamic capabilities that such advantages are sustained leading to sustained superior performance.

\subsection{Empirical Review}

Various empirical studies have been carried out to establish the effect of cost leadership strategy on performance. Kasman (2012) examined how cost efficiency and economies of scale affected technological growth among commercial banks in Turkey. The study observed that the banks took specific strategic orientations to align with their objectives. It used panel data from a usable sample of 48 private commercial banks. The study concluded that economies of scale positively influenced profitability. The sampling approach adopted in the study was largely purposive and economic models were used to establish the interaction among variables to the detriment of non-financial measures.

A study by Richter (2014) on manufacturing firms in Germany argued that internal informational costs declines with economies of scale owing to spread over larger or more markets thus lower cost per unit. The study collected panel financial data from a sample of 107 firms. The findings established that economies of scale significantly affected performance of manufacturing firms. Economies of scale was considered as an explanatory variable alongside cultural diversity and decentralization leaving out key drivers of cost leadership strategy. Matejova, Placek, Krapek, Pucek and Ochrana (2014) hypothesized that a relationship between economic performance and the size of a firm exists. The authors however noted that past empirical studies had failed to give conclusive findings on the relationship between per capita expenditure and size. The study used data on the local governments pre-school and primary school education. It concluded that economies of scale positively influenced performance of municipalities in Czech up to a certain level, beyond which disadvantages set in. The study relied on historical data.

Shah, Tahir, Anwar and Ahmad (2016) in their study argued that the size of a firm positively affected performance. The study surveyed 153 listed firms for the period 2004-2013. Regression analysis showed that economies of scale significantly influenced performance of listed companies in Pakistan Stock Exchange. The study's context was Asia and it relied on historical data. A study by Growitsch and Wetzel (2009) examined the question of which is more efficient between joint and separate production. In their study on European railways, the authors argued that economies of scope arising from integration of business operations could lead to technical or transactional advantages. The study targeted 54 railway companies from Europe for the period 2000 to 2004. It concluded that economies of scope positively influenced performance of integrated European railways. The study did not consider non-financial measures of performance.

Hartarska, Parmeter and Nadolnyak (2011) studied the concept of economies of scope among rural microfinance institutions (MFIs). The study argued that expansion in scope could be more cost efficient if done by the same MFIs. Data on 882 MFIs from 93 countries was collected from the Microfinance Information Exchange market database. The authors concluded that scope economies were on average positive mostly due to fixed cost with some diseconomies with higher complementary cost component. The study was cross-country hence high degree of industry variability. Zahavi and Lavie (2013) sought to understand how expansion into related product lines by a firm affects performance. The authors conducted a pooled time-series analysis of 156 firms operating between 1990 and 2001 using historical data from 1985. The study showed a U-shaped performance effect of economies of scope among USA based software firms. The study relied on historical data and was based in the USA.

A study by Sporta, Ngugi, Ngumi and Nanjala (2017) observed that high operational efficiency was a precursor for competitive advantage in industry. It collected secondary financial data on commercial banks in Kenya for the period 2005 to 2015. The findings indicated that operational efficiency significantly affected financial performance of the banks. The study was based on a service industry and was of longitudinal design. Azad, Raza and Zaidi (2018) observed that efficiency impacts on firm performance and as a consequence managers aim to improve the effectiveness of business operations. The authors argued that efficiency leads to quality production as well cost savings. The study surveyed secondary data of four companies of oil and gas exploration sector from 
2010 to 2015. Operational efficiency was found to positively impact profitability of firms in Pakistan energy sector. No sampling was done in the study due to the limited number of firms.

While the above studies generally point to a relationship between cost leadership strategy and firm performance, they were all based on other sectors. Further, the studies arrived at different conclusions in regard to the effects that drivers of cost leadership have. Kasman (2012) for instance shows linear relationship between economies of scale and firm performance while Matejova et al. (2014) indicate that the relationship is U-shaped. Similarly, Growitsch and Wetzel (2009) study shows that economies of scope linearly affects firm performance while Zahavi and Lavie (2013) concludes that the relationship between the two variables is U-shaped. In addition, studies done on milk processing firms in Kenya focused on corporate strategies as opposed to business level strategies and thus failed to address the cost challenges facing the milk processors (Mwangi \& Gakobo, 2018). The question therefore remains whether this relationship is a fact or fallacy in milk processing firms in Kenya. Consequently, this study proposes the hypothesis that:

$\mathbf{H}_{\mathbf{0 1}}$ Economies of scale has no significant effect on performance of milk processing firms in Kenya.

$\mathbf{H}_{02}$ Economies of scope has no significant effect on performance of milk processing firms in Kenya.

$\mathbf{H}_{\mathbf{0 3}}$ Operational efficiency has no significant effect on performance of milk processing firms in Kenya.

\section{Research Methodology}

The study used both descriptive and explanatory non-experimental research designs. Combining different designs is recommended in order to capture the best out of each and allow triangulation of research findings thus raising validity of the results (Saunders, Lewis \& Thornhill, 2009; Creswell \& Creswell, 2017; Wanjiru et al., 2019). The approach allowed the researcher to describe the phenomenon as it exists through the descriptive component and concurrently illustrate cause effect relationships through the explanatory component. Cost leadership strategy was measured using economies of scale, economies of scope and operational efficiency while firm performance was measured using both financial and non-financial indicators. The sampling frame consisted of the 29 milk processing firms registered with KDB as at June 2019. Out of these, 24 firms which processed less than 100,000 litres of milk per day were categorized as small representing 83\% while 5 firms which processed 100,000 litres and above per day were categorized as large representing $17 \%$.

The unit of analysis used in the study was milk processing firm while the units of observation were the managers and their deputies from various functional areas. Sampling was done using proportionate stratified random sampling technique. The key functional areas relevant to the study like executive, operations, production, finance and marketing were purposively identified giving a total of 194 key respondents in two categories. Proportionate samples were then randomly picked with a resultant sample size of 168 respondents. This large sample was picked to achieve better estimation of the population and smaller confidence intervals as recommended by Muathe (2010) and Field (2013). Data was collected using self-administered semi-structured questionnaires. Data analysis was done using descriptive and inferential statistics. This was aided by Statistical Package for Social Sciences software. The study was guided by the following empirical model:

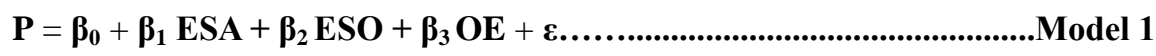

Where; $\mathrm{P}=$ Firm performance

$$
\begin{aligned}
& \text { ESA = Economies of scale } \\
& \text { ESO = Economies of scope } \\
& \text { OE = Operational efficiency } \\
& \beta_{\mathrm{i}}=\text { Beta Coefficient } \\
& \varepsilon=\text { Error term }
\end{aligned}
$$

\section{Findings and Discussion}

A total of 168 questionnaires were administered out of which 148 representing a response rate of $88.1 \%$ were duly filled and returned. According to Mugenda and Mugenda (2003), this was an excellent response rate.

\subsection{Descriptive Statistics}

The study used sample mean and sample standard deviation to summarize measures on the characteristics of the sample. The descriptive statistics results are shown in Table 1. 
Table 1. Descriptive Statistics of Cost Leadership Strategy

\begin{tabular}{lcc}
\hline Variable & Mean & Standard Deviation \\
\hline Economies of Scale & 3.97 & 0.94 \\
\hline Economies of Scope & 3.75 & 0.99 \\
\hline Operational Efficiency & 4.33 & 0.74 \\
\hline Average & $\mathbf{4 . 0 2}$ & $\mathbf{0 . 8 9}$ \\
\hline
\end{tabular}

Source: Survey Data (2020)

From Table 1, operational efficiency was the most adopted driver for cost leadership by the milk processing firms with a mean of 4.33 and standard deviation of 0.74 , then economies of scale with a mean of 3.97 and standard deviation of 0.94 while economies of scope was the least adopted driver for cost leadership with a mean of 3.75 and standard deviation of 0.99 .

\subsection{Diagnostic Tests}

To ensure that regression assumptions were adhered to and data was suitable for regression modeling, several diagnostic tests were conducted. The tests also ensured that results obtained were not spurious and could be used in predicting the effect of cost leadership strategy on performance of milk processing firms in Kenya. Sampling adequacy was tested using Keiser-Meyer-Olkin (KMO) and yielded a value of $0.828>0.5$ implying that the sample size was adequate as recommended by Field (2013). Normality test through Shapiro-Wilk Statistic showed that all variables had p-values greater than 0.05. According to Razali and Wah (2011), this indicated that data on the variables was normally distributed. The Durbin-Watson statistic for test of autocorrelation was 2.08 meeting the threshold of $1.5<\mathrm{d}<2.5$ given by Garson (2012). The Pearson's correlation coefficient for linearity showed that all variables had positive correlations while none of the variables exceeded Variance Inflation Factor (VIF) of 10 meaning there was no threat of multicollinearity (Field, 2009). Heteroscedasticity test on the other hand showed that all the variables had Levene statistics with p-value greater than 0.05 thus meeting the recommendation of Field (2013).

\subsection{Test of Hypothesis}

To establish the effect of cost leadership strategy on firm performance, cost leadership strategy was regressed on performance. The results of the regression analysis are shown in Table 2.

Table 2. Model Summary

\begin{tabular}{|l|l|l|l|}
\hline \multicolumn{1}{|c|}{$\mathbf{R}$} & \multicolumn{1}{|c|}{ R-Square } & Adjusted R-Square & Std. Error of the Estimate \\
\hline $.643 \mathrm{a}$ & 0.413 & 0.401 & 0.38517 \\
\hline \multicolumn{2}{|l|}{ Predictors: (Constant), Economies of Scale, Economies of Scope and Operational Efficiency } \\
\hline
\end{tabular}

Source: Survey Data (2020)

The results show adjusted R-square $=0.401$ which implied that the three constituent measures of CLS namely economies of scale, economies of scope and operational efficiency accounted for $40.1 \%$ of the variation in firm performance. These findings show that the cost leadership approaches are significant predictor variables of firm performance. The findings supported those of Kasman (2012), Hartarska et al. (2011) and Sporta et al. (2017) who concluded that economies of scale, economies of scope and operational efficiency respectively had positive and significant influence on firm performance. The results for ANOVA model fitness were statistically significant as shown in Table 3.

Table 3. ANOVA Results

\begin{tabular}{|l|c|c|c|c|c|}
\hline & Sum of Squares & df & Mean Square & F & Sig. \\
\hline Regression & 15.021 & 3 & 5.007 & 33.749 & $.000^{\mathrm{b}}$ \\
\hline Residual & 21.364 & 144 & .148 & & \\
\hline Total & 36.384 & 147 & & & \\
\hline & Dependent Variable: Firm Performance \\
\hline
\end{tabular}

Source: Survey Data (2020) 
Table 3 on overall ANOVA revealed F-statistic $=33.749$, which was significant at $5 \%$ level of significance $(\mathrm{p}=.000)$. The findings indicated that the model fitted had a goodness of fit and cost leadership approaches significantly explained performance of milk processing firms in Kenya since the model was statistically significant at 5 percent level of significance. The results concur with those of Nyauncho and Nyamweya (2015) and Gorondutse and Gawuna (2017) who concluded that cost leadership strategy positively affected firm performance. The results for model coefficients are presented in Table 4.

Table 4. Regression Model Coefficients

\begin{tabular}{|l|l|l|l|l|l|}
\hline & $\boldsymbol{\beta}$ & Std. Error & Beta & t & Sig. \\
\hline (Constant) & 0.923 & 0.324 & & 2.849 & 0.005 \\
\hline Economies of Scale & 0.135 & 0.059 & 0.175 & 2.307 & 0.022 \\
\hline Economies of Scope & 0.148 & 0.06 & 0.18 & 2.476 & 0.014 \\
\hline Operational Efficiency & 0.493 & 0.069 & 0.483 & 7.134 & 0.000 \\
\hline
\end{tabular}

Source: Survey Data (2020)

From the results in Table 4, the optimal model became;

$\mathrm{P}=0.923+0.135$ (Economies of Scale) +0.148 (Economies of Scope) +0.493 (Operational Efficiency).

The findings showed that the coefficient for economies of scale was $\beta=0.135, p=0.022<0.05$ signifying that economies of scale had a positive and significant effect on performance of milk processing firms in Kenya. The conclusion further implied that increase in economies of scale by one unit would lead to increase in performance of the milk processors by 0.135 units. The study thus rejected $\mathrm{H}_{02}$ that economies of scale has no significant effect on performance of milk processing firms in Kenya. This conclusion emphasizes the role that large scale operations play in reducing costs and as a consequence contribute to better firm performance. Large scale operations lead to lower average cost per unit produced as volumes increase (Barney \& Hesterly, 2009). Consequently, the firm enjoys greater benefits relative to competitors in the industry. These findings are consistent with those of Shah et al. (2016) who concluded that large firms had better financial performance. They also agree with findings by Kasman (2012) study which concluded that large banks in Turkey enjoyed cost advantages over the smaller banks hence performed better. They further relate with Richter (2014) conclusion that internal information costs per unit decreases among manufacturing firms as volume of operation increases.

However, based on Matejova et al. (2014) findings of a U-shaped cost curve where increasing economies of scale persist only up to certain level and thereafter cost disadvantages set in, firms should be cautious while expanding operations beyond the turning point. This would cushion them from suffering diseconomies of scale. The difference in conclusion can however be explained by the fact that Matejova et al. (2014) study was based on public service entities whose primary goal may not necessarily be cost minimization. From a theoretical perspective, the RBV argues that firms can perform better in an industry by doing things differently (Armstrong $\&$ Baron, 2004). Such superior advantage can be attained by applying various aspects of economies of scale in a unique manner.

On economies of scope, the findings showed a beta coefficient of $0.148, p=0.014<0.05$ implying that economies of scope had a positive and significant effect on performance of the milk processors. This also meant that increase in economies of scope by one unit would increase performance of the milk processors by 0.148 units. The study thus rejected $\mathrm{H}_{02}$ that economies of scope has no significant effect on performance of milk processing firms in Kenya. Contribution of economies of scope to performance was thus affirmed by this conclusion. The cost benefits under economies of scope accrue through joint production hence better asset utilization (Nyauncho \& Nyamweya, 2015).

The findings support Growitsch and Wetzel (2009) conclusion that integrated European railway firms were more efficient and enjoyed benefits from economies of scope. They are also consistent with Hartarska et al. (2011) who found that scope economies were on average positive mostly due to fixed cost. On the other hand, the findings partially contradict Zahavi and Lavie (2013) study conclusion of a U-shaped performance effect where too much product relatedness creates negative transfer effects. This means that even as firms expand into related areas they must be aware of possible negative cost and performance outcomes. These outcomes need to be examined broadly as advocated by BSC (Kaplan \& Norton, 1992)

The findings further indicated that the coefficient for operational efficiency was $\beta=0.493, p=0.000<0.05$ signifying that operational efficiency had a positive and significant effect on performance of the milk processing 
firms. The results implied that increasing operational efficiency by one unit would lead to increase in performance of the milk processors by 0.493 units. The study thus rejected $\mathrm{H}_{02}$ that operational efficiency has no significant effect on performance of milk processing firms in Kenya .This showed that milk processors were keen on improving their processes to attain superior performance.

The high beta value of 0.493 indicates the centrality of operational efficiency as a low cost driver. The study findings agreed with Sporta et al. (2017) who showed a positive relationship between operational efficiency and financial performance of banks in Kenya. This reaffirmed the need to efficiently utilize available resources as a precursor to superior performance. Further, findings by Azad et al. (2018) support the current study's findings by concluding that operational efficiency significantly impacts on firm's profitability. The findings also support CBV theory postulate that firms operate in dynamic environment requiring operational efficiency to cope with the changes. Efficiency also means that firms are able to switch between various cost approaches for best performance.

\section{Conclusion and Policy Recommendation}

\subsection{Conclusion}

The study sought to establish the effect of cost leadership strategy on performance of milk processing firms in Kenya. This objective was realized by examining how three drivers of cost leadership strategy namely economies of scale, economies of scope and operational efficiency influenced performance of the processors. All the three indicators of cost leadership strategy were found to have positive and significant relationship with performance of the milk processors. Overall, the findings showed that cost leadership strategy had a positive and significant affect on performance of the firms. From the findings, it can be concluded that milk processors in Kenya improve their performance by cutting costs through increasing their scale of operations, expanding into related business areas and improving operational processes.

\subsection{Policy Implications}

Based on the findings, the study recommends that milk processors should have policies that facilitate bulk production and investment in related businesses, adopt robust promotional efforts, encourage bulk purchases and innovate to support broad operations. This should be coupled with investment in storage space for both raw materials and finished products. Milk processors should also join relevant institutions to benefit from external support and institutionalize a culture of reuse and recycling to curb wastage. In addition, milk processing firms should pursue appropriate technologies to reduce costs including Information and Communication Technology (ICT) for marketing, Enterprise Resource Planning (ERP) software to manage operations and accounting packages to monitor costs. The government and other the regulatory bodies should implement supportive policies for large scale operations, facilitate licensing for investments in related areas, patent innovations by milk processors, issue guidelines on critical skills for key positions and safety standards, ensure conducive climate for dairy farming and implement credible livestock disease fighting programs. Some of the policy support approaches include tax rebates, tax incentives and zero rating some inputs.

\subsection{Limitations and Future Research}

This study considered milk processing firms registered with KDB as at June 2019 only and future studies should include small home-based milk processors as they may have significant impact on the industry. In addition, the study used perceptual scales to collect financial performance data of the milk processing firms using self administered questionnaires. Further studies should be done in the same area using secondary data from the firms' financial statements to collaborate the responses given. The study found that cost leadership strategy accounted for $40.1 \%$ of the variation in performance of milk processing firms in Kenya. Therefore, further studies should focus on other factors besides the cost leadership approaches studied that explain the remaining variation in performance of milk processing firms in Kenya.

\section{References}

Anwar, R. S., \& Ali, S. (2015). Economies of scale. International Interdisciplinary Journal of Scholarly Research, 1(1), 51-57.

Armstrong, M., \& Baron, A. (2004). Strategic HRM: The key to improved business performance. CIPD. London.

Atikiya, R., Mukulu, E., Kihoro, J., \& Waiganjo, E. (2015). Effect of cost leadership strategy on the performance of manufacturing firms in Kenya. Journal of Management, 2(8), 134-143.

Azad, A. M. S., Raza, A., \& Zaidi, S. S. Z. (2018). Empirical relationship between operational efficiency and profitability (Evidence from Pakistan Exploration Sector). Journal of Accounting, Business and Finance 
Research, 2(1), 7-11. https://doi.org/10.20448/2002.21.7.11

Barney, J. (1991). Firm resources and sustained competitive advantage. Journal of Management, 17(1), 99-120. http://doi.org/10.1177/014920639101700108

Barney, J. B. (2001). Is the resource-based "view" a useful perspective for strategic management research? Yes. Academy of Management Review, 26(1), 41-56. http://doi.org/10.2307/259393

Barney, J. B., \& Hesterly, W. S. (2009). Strategic management and competitive advantage. Pearson Education. Upper Saddle River, NJ.

Bebe, B. O., Rademaker, C. J., Lee, J., Kilelu, C. W., \& Tonui, C. (2017). Sustainable growth of the Kenyan dairy sector. Wageningen University and Research. Wageningen. https://doi.org/10.18174/413390

Birjandi, H., Jahromi, N. M., Darasi, S. M., \& Birjandi, M. (2014).The effect of cost leadership strategy on ROA and future performance of accepted companies in Tehran Stock Exchange. Research Journal of Finance and Accounting, 5(70), 152-158.

Booyse, N. J. (2018). Development of a school-based performance management framework for self-managing schools in South Africa. [Doctoral thesis, University of South Africa].

Chege, P. M., \& Oloko, M. (2017). Influence of generic strategies on performance of large dairy firms in Kenya. European Journal of Business and Management, 9(30).

Chong, H. G. (2008). Measuring performance of small-and-medium sized enterprises: the grounded theory approach. Journal of Business and Public affairs, 2(1), 1-10.

Creswell, J. W., \& Creswell, J. D. (2017). Research design: Qualitative, quantitative, and mixed methods approaches. Sage Publications.

Dhillon, A. S., \& Vachhrajani, H. (2012). Impact of Operational Efficiency on Overall Profitability-A Case Study of GIPCL (No. 136). Working Paper.

Echwa, M., \& Murigi, E. M. (2019). Strategic leadership and performance of domestic airline firms in Kenya. Eastern Africa Journal of Contemporary Research, 1(2), 144-152.

Elif, G. E. N. Ç., \& Şengül, R. (2015). A review on the relationship between strategic management and performance: The role of internal and external contexts. Strategic Public Management Journal, 1(2), 56-71. https://doi.org/10.25069/spmj.290425

Espirah, J. O., \& Murigi, E. M. (2019). Effect of Strategy Execution on Performance of Parliamentary Service Commission of Kenya. Journal of Public Policy \& Governance, 3(2), 61-72.

Fatoki, O. O. (2011). The impact of human, social and financial capital on the performance of small and medium-sized enterprises (SMEs) in South Africa. Journal of Social Sciences, 29(3), 193-204. https://doi.org/10.1080/09718923.2011.11892970

Field, A. (2009). Discovering Statistics using SPSS. Sage. London, UK.

Field, A. (2013). Discovering statistics using IBM SPSS statistics. Sage. London, UK.

Garson, G. D. (2012). Testing statistical assumptions. Statistical Associates Publishing. North Carolina.

Gill, A., Singh, M., Mathur, N., \& Mand, H. S. (2014). The impact of operational efficiency on the future performance of Indian manufacturing firms. International Journal of Economics and Finance, 6(10), 259. https://doi.org/10.5539/ijef.v6n10p259

Gill, I. S., \& Goh, C. C. (2009). Scale economies and cities. The World Bank Research Observer, 25(2), 235-262. https://doi.org/10.1093/wbro/lkp022

Gorondutse, A. H., \& Gawuna, M. S. (2017). Cost leadership strategy and performance of hotels in Nigerian context. Journal of Applied Structural Equation Modeling, 1(1), 1-12. https://doi.org/10.47263/JASEM.1(1)02

Government of Kenya. (2020). Enhanced national response to the Coronavirus (COVID-19) pandemic: Classification of critical and essential services. Public Order Number 1 on the Coronavirus pandemic.

Growitsch, C., \& Wetzel, H. (2009). Testing for economies of scope in European railways: An efficiency analysis. Journal of Transport Economics and Policy (JTEP), 43(1), 1-24.

Hansen, E., Nybakk, E., \& Panwar, R. (2015). Pure versus hybrid competitive strategies in the forest sector: Performance implications. Forest Policy and Economics, 54, 51-57. 
https://doi.org/10.1016/j.forpol.2015.02.001

Harreld, J. B., O'Reilly III, C. A., \& Tushman, M. L. (2007). Dynamic capabilities at IBM: Driving strategy into action. California Management Review, 49(4), 21-43. https://doi.org/10.2307/41166404

Hartarska, V., Parmeter, C. F., \& Nadolnyak, D. (2011). Economies of scope of lending and mobilizing deposits in microfinance institutions: A semi-parametric analysis. American Journal of Agricultural Economics, 93(2), 389-398. https://doi.org/10.1093/ajae/aaq108

Hilman, H., \& Kaliappen, N. (2014). Do cost leadership strategy and process innovation influence the performance of Malaysia hotel industry? Asian Social Science, 10(10), 134. https://doi.org/10.5539/ass.v10n10p134

Hoque, Z. (2014). 20 years of studies on the balanced scorecard: Trends, accomplishments, gaps and opportunities for future research. The British Accounting Review, 46(1), 33-59. https://doi.org/10.1016/j.bar.2013.10.003

Hubbard, G. (2009). Measuring organizational performance: Beyond the triple bottom line. Business Strategy and the Environment, 18(3), 177-191. https://doi.org/10.1002/bse.564

Kaplan, R. S. (2009). Conceptual foundations of the balanced scorecard. Handbooks of Management Accounting Research, 3(1)1253-1269. https://doi.org/10.1016/s1751-3243(07)03003-9

Kaplan, R. S., \& Norton, D. P. (1992). The balanced scorecard-measures that drive performance. Harvard Business Review, 70(1), 71-79.

Karanja, S. C., Muathe, S. M. A., \& Thuo, J. K. (2014). Marketing capability and the performance of mobile service provider intermediary organizations in Nairobi County, Kenya. International Journal of Education and Research, 2(5), 499-512. https://doi.org/10.5296/bms.v5i1.5723

Kasman, A. (2012). Cost efficiency, scale economies, and technological progress in Turkish banking. Central Bank Review, 2(1), 1-20.

Kathama, L. K. (2012). Strategic planning practices and performance of state corporations in Kenya [Doctoral dissertation, University of Nairobi].

Kenya Agribusiness and Agroindustry Alliance. (2014). Agriculture investment opportunities in Kenya dairy processing investment case.

Kenya Dairy Board (2019). Kenya Dairy Board report. Retrieved from https://www.kdb.go.ke/dairy-data/

Kiiru, D. M. (2015). Strategic human resource management practices and performance of parastatals in Kenya [Doctoral dissertation, Kenyatta University].

Kimiti, P. G., \& Kilika, J. M. (2018). Organizational resources, industry velocity, attention focus and firm's performance: A review of literature. International Journal of Business and Management, 13(5), 185. https://doi.org/10.5539/ijbm.v13n5p185

Kirima, M. W., \& Murigi, E. M. (2019). Demographic perspectives and organizational performance in Occidental Insurance Company. European Journal of Business and Strategic Management, 4(1), 30-38.

Krylov, S. (2019). Strategic customer analysis based on balanced scorecard. Ekonomicko-manazerske spektrum, 13(1), 12-25. https://doi.org/10.26552/ems.2019.1.12-25

Kyengo, J. M., Muathe, S. M. A., \& Kinyua, G. M. (2019). Marketing capability and firm performance: An empirical analysis of food processing firms in Nairobi City County, Kenya. The Strategic Journal of Business \& Change Management, 6(1), 544-555. https://doi.org/10.14445/23939125/IJEMS-V6I5P117

Martello, M., Watson, J. G., \& Fischer, M. J. (2016). Implementing a balanced scorecard in a not-for-profit organization. Journal of Business and Economics Research, 14(3), 61-98. https://doi.org/10.19030/jber.v14i3.9746

Matejova, L., Placek, M., Krapek, M., Pucek, M., \& Ochrana, F. (2014). Economies of scale-empirical evidence from the Czech Republic. Procedia Economics and Finance, 12(1) 403-411. https://doi.org/10.1016/s2212-5671(14)00361-x

Ministry of Agriculture, Livestock and Fisheries. (2013). Towards a Competitive and Sustainable Dairy Industry for Economic Growth in the $21^{\text {st }}$ Century and Beyond. Sessional Paper No. 5 of 2013 on the National Dairy Development Policy. 
Monsur, S. M. T., \& Yoshi, T. (2012). Improvement of firm performance by achieving competitive advantages through vertical integration in the apparel industry of Bangladesh. Asian Economic and Financial Review, 2(6), 687.

Mosheim, R., \& Lovell, C. K. (2009). Scale economies and inefficiency of US dairy farms. American Journal of Agricultural Economics, 91(3), 777-794. https://doi.org/10.1111/j.1467-8276.2009.01269.x

Muathe, S. M. A. (2010). The Determinants of Adoption of Information and Communication Technology by Small and Medium Enterprises within the Health Sector in Nairobi, Kenya. Unpublished PhD Thesis, Kenyatta University.

Mugenda, O. M., \& Mugenda, A. G. (2003). Research methods. Laba Graphics Services Ltd. Nairobi.

Mwangi, E. W., \& Gakobo, J. (2018). Growth strategies and performance of selected milk processing companies in Kenya. International Journal of Contemporary Aspects in Strategic Management, 2(1), 158-172.

Niven, P. R. (2011). Balanced scorecard: Step-by-step for government and nonprofit agencies. John Wiley \& Sons. https://doi.org/10.1002/9781119197287

Njoroge, J. K., Ongeti, W. J., Kinuu, D., \& Kasomi, F. M. (2016). Does external environment influence organizational performance? The case of Kenyan State Corporations. Management and Organizational Studies, 3(3), 41-51. https://doi.org/10.5430/mos.v3n3p41

Nyauncho, N. M., \& Nyamweya, N. I. (2015). Assessment of the effect of cost leadership strategy on the performance of Liquefied Petroleum Gas Companies in Eldoret town, Uasin Gishu County, Kenya. International Journal of Business and Management Invention, 4(4), 1-7.

Ongeti, O. W. (2014). Organizational resources, corporate governance structures and performance of Kenyan state corporations. [Doctoral dissertation, University of Nairobi].

Ormanidhi, O., \& Stringa, O. (2008). Porter's model of generic competitive strategies. Business Economics, 43(3), 55-64.

Penrose, E. T. (1959). The theory of the growth of the firm. John Wiley \& Sons. New York.

Razali, N. M., \& Wah, Y. B. (2011). Power comparison of Shapiro-Wilk, Kolmogorov-Smirnoff, Lilliefors and Anderson-Darling Tests. Journal of Statistical Modeling and Analytics, 2(1), 21-33.

Richter, N. F. (2014). Information costs in international business: Analyzing the effects of economies of scale, cultural diversity and decentralization. Management International Review, 54(2), 171-193. https://doi.org/10.1007/s11575-013-0187-y

Sainaghi, R., Phillips, P., \& d'Angella, F. (2019). The balanced scorecard of a new destination product: Implications for lodging and skiing firms. International Journal of Hospitality Management, 76, 216-230. https://doi.org/10.1016/j.ijhm.2018.05.011

Sakhartov, A. V. (2017). Economies of scope, resource relatedness, and the dynamics of corporate diversification. Strategic Management Journal, 38(11), 2168-2188. https://doi.org/10.1002/smj.2654

Saunders, M., Lewis, P., \& Thornhill, A. (2009). Research methods for business. Pearson Education. London.

Shah, S., Tahir, S. H., Anwar, J., \& Ahmad, M. (2016). Does size matter in determining firms' performance? A comparative analysis of listed companies. City University Research Journal, 6(2), 344-353.

Spanos, Y. E., Zaralis, G., \& Lioukas, S. (2004). Strategy and industry effects on profitability: Evidence from Greece. Strategic Management Journal, 25(2), 139-165. https://doi.org/10.1002/smj.369

Sporta, F. O., Ngugi, P. K., Ngumi, P. M., \& Nanjala, C. S. (2017). The effect of operational efficiency as a financial distress factor on financial performance on commercial banks in Kenya. The International Journal of Business and Management, 5(7) 102-112.

Stalk, G., Evans, P., \& Shulman, L. E. (1992). Competing on capabilities: The new rules of corporate strategy. Harvard Business Review, 70(2), 57-69.

Sundin, H., Granlund, M., \& Brown, D. A. (2010). Balancing multiple competing objectives with a balanced scorecard. European Accounting Review, 19(2), 203-246. https://doi.org/10.1080/09638180903118736

Teece, D. T., Pisano, G., \& Shuen, A. (1997). Dynamic capabilities and strategic management. Strategic Management Journal, 18(7), 509-533.

https://doi.org/10.1002/(SICI)1097-0266(199708)18:7<509::AID-SMJ882>3.0.CO;2-Z 
Teece, D., \& Pisano, G. (1994). The dynamic capabilities of firms: An introduction. Industrial and Corporate Change, 3(3), 537-556. https://doi.org/10.1093/icc/3.3.537-a

Theodosiou, M., Kehagias, J., \& Katsikea, E. (2012). Strategic orientations, marketing capabilities and firm performance: An empirical investigation in the context of frontline managers in service organizations. Industrial Marketing Management, 41(7), 1058-1070. https://doi.org/10.1016/j.indmarman.2012.01.001

Wambugu, S., Kirimi, L., \& Opiyo, J. (2011). Productivity trends and performance of dairy farming in Kenya. Tegemeo Institute of Agricultural Policy and Development. Egerton University.

Wanjiru, A. I., Muathe, S. M., \& Kinyua-Njuguna, J. W. (2019). The mediating effect of competitive advantage on the relationship between corporate strategies and performance of manufacturing firms in Nairobi City County, Kenya. Journal of Business and Management (IOSR-JBM), 21(4), 7-15. https://doi.org/10.5430/jms.v10n4p21

Zahavi, T., \& Lavie, D. (2013). Intra-industry diversification and firm performance. Strategic Management Journal, 34(8), 978-998. https://doi.org/10.1002/smj.2057

\section{Copyrights}

Copyright for this article is retained by the author(s), with first publication rights granted to the journal.

This is an open-access article distributed under the terms and conditions of the Creative Commons Attribution license (http://creativecommons.org/licenses/by/4.0/). 